\title{
Fermented Technology of Robusta Coffee Beans (Canephora Coffee) With Kefir Milk to Produce Specialty Coffee
}

\author{
Asmak Afriliana, Hiroyuki Harada \\ Department of Environmental Science \\ Faculty of Life and Environmental Science, \\ Prefectural University of Hiroshima \\ Shobara, Japan. \\ E-mail: asmak.ftp@unej.ac.id
}

Giyarto.

Department of Agricultural Product Faculty of Agricultural Technology, University of Jember Jember, Indonesia.

\author{
Putri Qoriasiatul Khotijah, \\ Department of Agricultural Product \\ Faculty of Agricultural Technology, \\ University of Jember \\ Jember, Indonesia. \\ E-mail: putriqori19@gmail.com
}

\author{
Jayus. \\ Department of Agricultural Product \\ Faculty of Agricultural Technology, \\ University of Jember \\ Jember, Indonesia.
}

\author{
Hiroyuki Harada \\ Department of Environmental Science \\ Faculty of Life and Environmental Science, \\ Prefectural University of Hiroshima \\ Shobara, Japan
}

\begin{abstract}
Coffee beans produced by Indonesian farmers are known as "asalan" (unfermented) coffee and has a bad taste. The aims of this research to increase quality of Robusta coffee bean with fermentation using kefir starter. It is one of processing methods of coffee by soaking the coffee beans and then adding starter kefir $1: 2: 3 \%$ and lactose $1: 3 \%$. Fermentation time is 12 hours with temperature $28^{0} \mathrm{C}$. Based on data of total calculation of Lactic Acid Bacteria (LAB), it was known that all coffee samples had increased. Scores of pH coffee beans were 5.7 ; 5.6; $5.5 ; 5.4$. The final scores of cuptest of coffee were respectively 81.08; 81.83; $77.33 ; 78 ; 80.25 ; 80.50 ; 78.33 ; 79.67$. Total flavor components of Robusta coffee were 73 components for control/unfermented, A1B2 sample of 82 components, and A2B1 sample of 66 components. Fermentation process of Robusta coffee beans with kefir and lactose has a real effect on the quality of coffee produced. There were 4 coffee samples which received specialty coffee, sample A1B1 with score of 81.08, sample A1B2 with score of 81.83, sample A3B1 with score of 80.25 , and sample A3B2 with score of 80.50 .
\end{abstract}

Keywords-Kefir, Lactic Acid Bacteria (LAB), asalan Robusta coffee, Lactose, Specialty Coffee

\section{INTRODUCTION}

Coffee is one of the commodities cultivated by almost 50 countries in the world. One of which is Indonesia. The most common types of coffee consumed include Robusta and Arabica coffee. According to the Directorate General of Plantation in 2017, it is estimated that Robusta coffee plantation area in Indonesia reaches 898,145 hectares with total coffee production of 463,775 tons, consisting of 438,823 tons of Robusta coffee from smallholder plantations, 9,145 tons from state-owned plantations and 15,807 from private plantations.
Based on data from the Directorate General of Plantation [1], it is known that $94.62 \%$ of the Robusta coffee plant is derived from plantations owned by farmers independently. The coffee beans produced by Indonesian farmers are known as "root coffee" because they generally have a low quality with a defect value of over 225 [2]. This type of defective seed is very unpopular because it will produce the characteristics of stink, ferment, musty/moldy/earthy [3]. According to Yusianto and Widyotomo [4], the original Robusta coffee was created because post-harvest processing is done with very simple methods and facilities, so that the relative water content is high and still mixed with other materials in relatively large quantities. Dry coffee processing methods are mostly done by farmers because of the ease of implementation technology, but it can cause Robusta coffee has low [5].

The application of semi-wet processing technology to postharvest coffee is one of the efforts to improve the coffee quality of the people. This fermentation process can occur, with the help of microorganisms and lactic acid bacteria called fermentation and curing processes. One starter that can be used is a microbe in kefir. Kefir is milk fermented by several microbes and has been produced since ancient times in the Caucasus and spread throughout the world [6]-[8]. Starter culture is irregularly shaped, small, chewy white or yellow which is a combination of live bacteria. Types of microbes in kefir identified are Leuconostoc mesenteroides (29\%), Lactococcus lactis spp. (5\%), Lactococcus lactis spp. Cremoris (45\%), Acetobacter lovaniensis (10\%), and Saccharomyces cerevisiae (11\%) and fermentation produced lactic acid and alcohols [9]-[13]. The reason for using kefir, because it is easy to obtain and contains 
many types of microbes, so symbiosis will occur and accelerate the fermentation process [14].

The result of the expected Robusta coffee fermentation is Robusta specialty coffee. The meaning of specialty coffee is coffee that has more than 80 flavors [15]. According to Saragih, specialty coffee is a coffee different from coffee in general which is indicated by the final value of the test [16]. In this study the coffee used is not in the form of coffee cherry, but the dried beans of Robusta coffee. Thus, to improve the taste of coffee it needs fermentation technology. Therefore, research needs to be done on the use of concentration of kefir milk and lactose fermentation media to obtain Robusta specialty coffee.

\section{METHODS}

The research was conducted by fermentation of Robusta coffee beans, calculating the amount of lactic acid bacteria (LAB), $\mathrm{pH}$ value measurement, cup test and volatile coffee compounds by GC-MS.

\section{A. Fermented Asalan Robusta Coffee Beans}

In coffee making, the first step that must be done was to sort the seeds of Robusta coffee from seeds as well as foreign objects. Broken seeds and foreign objects will disrupt microbial work and affect coffee flavor. After that, the clean coffee beans were weighed 1000 grams and then soaked for 4 hours using aquadest as much as 2 liters or 1:2 which aims to imbibition process of dried Robusta bean. Imbibition causes an increase in the weight of coffee beans because of the water that seeps into the coffee beans. After wet Robusta coffee seeds were drained, the coffee seeds were given 8 different treatments; that is, differences in the concentration of milk kefir $0 ; 1 ; 2 ; 3 \%$, and lactose powder 1 and $3 \%$. The fermentation process was carried out for 12 hours with an anaerobic temperature of $28 \mathrm{oC}$, after that washing coffee beans using water until they were clean. Furthermore, the process of drying used oven for 48 hours with a temperature of $50 \mathrm{oC}$ to reduce the water content of coffee beans. The use of oven-drying can minimize the occurrence of contamination instead sun-drying. In addition, oven-drying can control the temperature, therefore the quality of fermented coffee is maintained. The next step was done by roasting process using temperature of $170 \mathrm{oC}$ for 9 minutes (medium roasting) using a coffee roasting machine to form a flavor and reduce the water content of coffee. After roasting, the last step was grinding the fermented coffee to produce coffee powder [17]-[18].

\section{B. Calculation of Total Lactic Acid Bacteria (LAB)}

The method used for calculating the number of LAB was Fardiaz method [19]; that is, by pouring method using MRSA media (de Mann Rogosa Sharpe Agar). A total of 5 grams of the sample were diluted into $45 \mathrm{ml}$ of physiological solution to obtain 10-1 dilution. Then, pipet as much as $1 \mathrm{ml}$ was put into a tube containing $9 \mathrm{ml}$ of $0.85 \% \mathrm{NaCl}$ solution to obtain 10-2 up to 10-7 dilution. Subsequently, inoculation by pouring method was taken from the last three retailing levels of 10-5, 10-6 and
10-7. From each dilution was taken $1 \mathrm{ml}$ with a pipette, put in a sterile petri dish. Further, it was poured as much as $15 \mathrm{ml}$ of MRSA (deMann Rogosa Sharpe Agar) which had been added with $1 \% \mathrm{CaCO} 3$ and had been cooled to $47-50 \mathrm{oC}$ and was rocked slowly. After solidifying, it was incubated for 24-48 hours with a temperature of $37 \mathrm{oC}$. MRSA is a medium for growing $\mathrm{LAB}$ microbes. $\mathrm{CaCO} 31 \%$ was used for growing LABs to form clear zones. Lactic acid metabolites from LAB will react with $\mathrm{CaCO} 3$ which produces lactate calcium in which the lactate calcium will produce clear zone and is used as an indicator of the calculation of the number of LABs.

\section{Measurement of $\mathrm{pH}$ Value of Coffee Beans}

The $\mathrm{pH}$ value measurements were performed by Muchtadi et al [20]. using a calibrated $\mathrm{pH}$ meter with buffer $\mathrm{pH} 7$ and buffer $\mathrm{pH}$ 4. The fermented beans were reduced in size. Robusta coffee beans that had been destroyed were dissolved using aquadest with a ratio of the amount of coffee and aquadest 1:3. Then, the $\mathrm{pH}$ value was measured by placing the electrode on the sample and the $\mathrm{pH}$ value could be seen on the $\mathrm{pH}$ screen meters.

\section{Cup Test of Robusta Coffee}

Testing of flavor/cup test was done by UCDA method [21] by preparing $150 \mathrm{ml}$ coffee cup as much as 5 cups for 1 sample. Each cup contained roasted coffee 10-11 grams. Brewing was done with the ratio of coffee and water as much as 1:10 and water temperature $99 \mathrm{oC}$. The first test performed was the fragrance test (the aroma of coffee in dry form). Further, testing the aroma of coffee was done by brewing coffee using hot water and letting it stand or 5 minutes for coffee extracted optimally. Testing the aroma of coffee was performed by breaking the floating layer of coffee and the aroma. Testing the taste of coffee was done by taking 1 tablespoon of soaking coffee and then inhaling and perceiving the flavor, aftertaste, saltiness/acidity, bitterness/sweetness, cleaness, uniform cup, overalls and flavor defects. The mouthfeel/body test was performed by taking 1 tablespoonful of coffee and then rubbing the coffee into the palate and feeling. The description of the score in the test cup test parameters was divided into 5 categories which be follows:
a. Average: $5.00-5.75$
b. Good: $6.00-6.75$
c. Very good: $7.00-7.75$
d. Excellent: $8.00-8.75$
e. Outstanding: $9.00-9.75$

\section{E. Volatile Compounds of Robusta Coffee by GC-MS}

Testing of volatile compounds according to Agresti et al., (2008) have done with the initial stage of inserting coffee powder $(3 \mathrm{ml}$ ) in a $5 \mathrm{ml}$ vial. Then the sample was heated with temperature $70 \mathrm{oC}$ for 10 minutes. The SPME needle was subsequently inserted into the vial and the fiber directed in the empty cavity above the coffee sample with a temperature of $70 \mathrm{oC}$ for 40 minutes.

This test used SPME within 3 phases (divinylbenzene/carboxen/polymethylsiloxane) with fiber of $50 / 30 \mu \mathrm{m}$. Thereafter, the fibers which had absorbed the volatile 
compound were introduced into the GC at a temperature of $250^{\circ} \mathrm{C}$ for 10 minutes. The columns used were RTX-5MS $(5 \%$ diphenyl, 95\% dimethyl polysiloxane) $30 \mathrm{~m}$ x $0.25 \mathrm{~mm}$ internal diameter and carrier gas Helium at a speed of $1 \mathrm{ml} / \mathrm{min}$. The injection temperature was set to $250 \mathrm{oC}$. The temperatures of the ions and interfaces were $300 \mathrm{oC}$ and $275 \mathrm{oC}$ respectively. The GC oven temperature was adjusted from $40 \mathrm{oC}(5 \mathrm{~min})$ to $180 \mathrm{oC}$ at $3 \mathrm{oC} / \mathrm{min}$, and then were increased again to $250 \mathrm{oC}(5 \mathrm{~min})$ at $10 \mathrm{oC} / \mathrm{min}$. GC Injector was set in splitless mode.

\section{RESULT AND DISCUSSION}

\section{A. Total Lactic Acid Bacteria (LAB)}

The results of calculation of total lactic acid bacteria (LAB) at the 0 and 12 hours of fermentation can be seen in Figure 3.1. Based on calculation data of total lactic acid bacteria (LAB), it can be known that the amount of LAB grows at 0 hour A1B1 sample; A1B2; A2B1; A2B2; A3B1; A3B2; A4B1; A4B2 respectively $0 ; 0 ; 4.76 ; 4.80 ; 5.91 ; 5.96 ; 6.22 ; 6.31$, while in the 12 hour sample successively $0 ; 2.54 ; 5.05 ; 5.22 ; 6.13 ; 6.19$; 7.36; 7.45. Based on the LAB total data in Figure 4.1, the A1B1 coffee samples at the 0 and 12 hours were not overgrown with $\mathrm{LAB}$, because the sample was not given additional kefir starter, while $\mathrm{A} 1 \mathrm{~B} 2$ at 12 hours, LAB grows spontaneously. This can be due to the condition when fermentation involves many LABs from the environment which also converts the lactose media into organic acids. In addition, based on the calculation of total data LAB samples A1B1 to A4B2, the more added kefir starter and lactose media, will increase the number of growing LAB. Several factors affecting microbial growth are the availability of nutrients, water, $\mathrm{pH}$, oxygen, reducing sugar, presence of inhibitors, and the presence of other microorganisms.

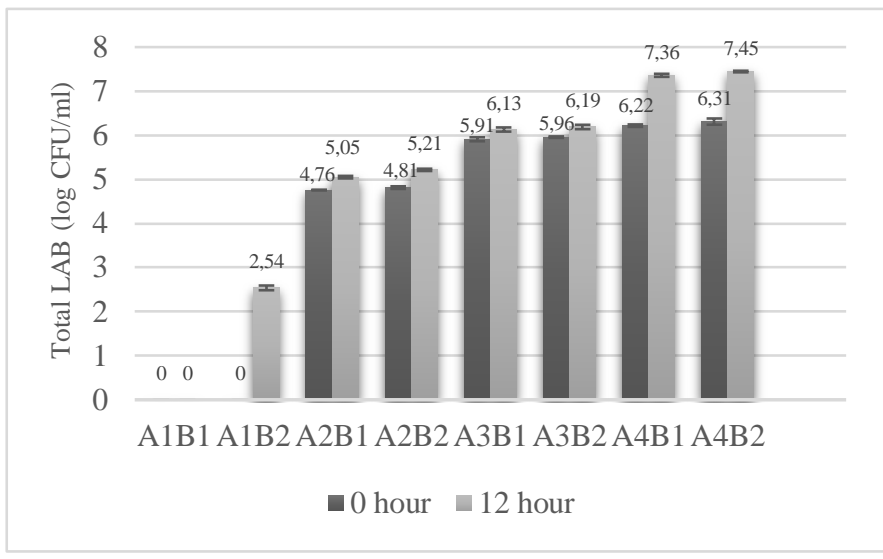

Figure 3.1 Total Lactic Acid Bacteria (LAB) 0 hour and 12 hours; A1B1 $(0 ; 1)$, A1B2 $(0 ; 3), \mathrm{A} 2 \mathrm{~B} 1(1 ; 1), \mathrm{A} 2 \mathrm{~B} 2(1 ; 3)$, A3B1 (2;1), A3B2 (2;3), A4B1 (3;1), A4B2 (3;3)

Based on Figure 3.1 all coffee samples have an increase in the number of LAB; this can be influenced by the amount of starter concentration of kefir and lactose added as substrate or growth medium of LAB. According to Maccabe et al., [22], the main food substance for the growth of microorganisms is the source of carbon, nitrogen, and mineral components. In this case, lactose acts as a carbon source of growth of LAB in kefir. Lactose will be broken down into simpler forms of galactose and glucose. The presence of glucose during the fermentation process can increase the growth of microbes. This is supported by Budiman [23] who states that the length of incubation is closely related to the time that can be used by microbes to grow and multiply. The longer the fermentation time, the more the substance the LAB uses for its growth.

\section{B. Changes in $\mathrm{pH}$ Value of Coffee Beans after Fermentation}

The results of measurement of $\mathrm{pH}$ value of coffee beans after fermentation can be seen in Figure 3.2.

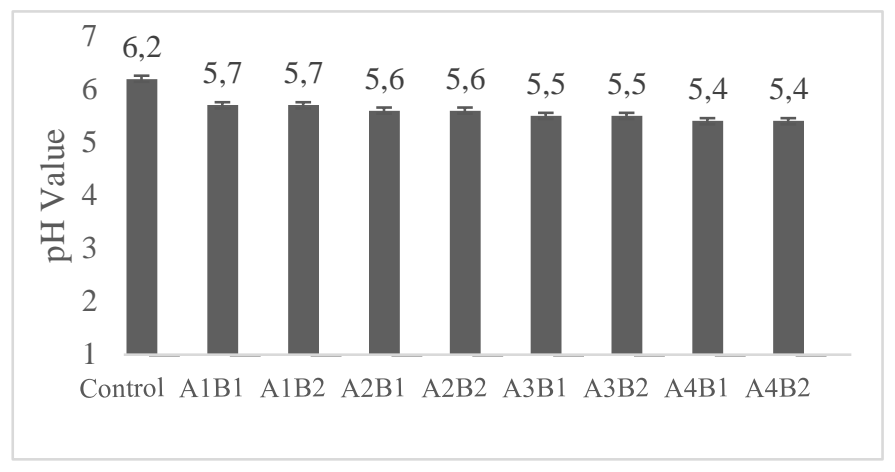

Based on Figure 3.2, the $\mathrm{pH}$ value decreases. Non-treated control or coffee $\mathrm{pH}$ value was 6.2. Coffee samples A1B1 and $\mathrm{A} 1 \mathrm{~B} 2$ have a $\mathrm{pH}$ value of 5.7, while coffees $\mathrm{A} 2 \mathrm{~B} 1$ and $\mathrm{A} 2 \mathrm{~B} 2$ have a $\mathrm{pH}$ value of 5.6. Coffee samples $\mathrm{A} 3 \mathrm{~B} 1$ and $\mathrm{A} 3 \mathrm{~B} 2$ have $\mathrm{pH}$ value of 5.5, while coffees $\mathrm{A} 4 \mathrm{~B} 1$ and $\mathrm{A} 4 \mathrm{~B} 2$ have $\mathrm{pH}$ value of 5.4 .

Coffee given the addition of kefir starter and lactose media decreases significant $\mathrm{pH}$ of control coffee which was not given any additional substance. The more concentration of the added kefir starter, the more $\mathrm{pH}$ value decreases or the acidity increases. This is in accordance with the total calculation data LAB because the higher amount of lactic acid bacteria leads to the increase of acidity level. Fermentation can cause the $\mathrm{pH}$ of coffee beans to decline due to the breakdown of sugar or caffeine to be converted into acidic compounds such as lactic acid, acetate, butyric and propionate. These bacteria breaking sugar for 5 to 24 hours during fermentation, because of breakdown of sugars such as lactic acid and acetic acid with greater lactic acid content and affect the acidity level.

The decline in $\mathrm{pH}$ values is also reported by Wilujeng and Wikandari (2013), stating that the length of fermentation will decrease $\mathrm{pH}$ due to amylolitic activity that degrades starch to glucose and then becomes lactic acid [24]. This is supported by Wardani [25], pointing out that during fermentation, lactic acid bacteria will convert lactose into lactose glucose and galactose and then become lactic acid and make the $\mathrm{pH}$ decrease. Acidity in coffee is produced from chlorogenic acid, acetic acid, and other non-volatile acids. Acetic acid is obtained by reshuffling glucose, lactose, sucrose, raffinosa, and stakiosa through 
glycolysis process. The length of fermentation process will be the proliferation of acidic bacteria which leads to the increase of organic acids produced. The formed acids will be released into the environment causing changes in acidity.

\section{Cup Test of Robusta Coffee Beans After Fermentation}

Cup Test of Robusta coffee include criteria: fragrance/flavor, flavor, aftertaste, acidity, sweetness, mouthfeel/body, uniform cup, balance, clean cup, overall, and final score can be seen on Table 3.1.

Table 3.1 Cup test of Robusta Coffee Beans

\begin{tabular}{|c|c|c|c|c|c|c|c|c|c|}
\hline \multirow{2}{*}{$\begin{array}{l}\text { Charachte } \\
\text { ristic }\end{array}$} & \multicolumn{9}{|c|}{ Sample } \\
\hline & $\begin{array}{l}\text { A1B } \\
1\end{array}$ & $\begin{array}{l}\text { A1 } \\
\text { B2 }\end{array}$ & $\begin{array}{l}\text { A2 } \\
\text { B1 }\end{array}$ & $\begin{array}{l}\text { A2 } \\
\text { B2 }\end{array}$ & $\begin{array}{l}\text { A3 } \\
\text { B1 }\end{array}$ & $\begin{array}{l}\text { A3 } \\
\text { B2 }\end{array}$ & $\begin{array}{l}\text { A4 } \\
\text { B1 }\end{array}$ & A4B2 & $\mathbf{K}$ \\
\hline Fragrance & 7.58 & 7.58 & 7.42 & 7.17 & 7.42 & 7.75 & 7.25 & 7.42 & 7.42 \\
\hline Flavor & 7.67 & 7.75 & 7.42 & 7.17 & 7.42 & 7.5 & 7.17 & 7.33 & 7.58 \\
\hline Aftertaste & 7.50 & 7.67 & 7 & 7.75 & 7.42 & 7.33 & 7.92 & 7.17 & 7.42 \\
\hline Acidity & 7.75 & 7.83 & 6.83 & 7.58 & 7.75 & 7.83 & 7.42 & 7.8 & 7.42 \\
\hline Sweetness & 7.67 & 7.92 & 6.83 & 7.33 & 7.58 & 7.42 & 7.5 & 7.58 & 7.17 \\
\hline Mouthfeel & 7.75 & 7.67 & 7.67 & 7.58 & 7.75 & 7.67 & 7.67 & 7.58 & 7.92 \\
\hline $\begin{array}{l}\text { Uniform } \\
\text { Cup }\end{array}$ & 10 & 10 & 10 & 10 & 10 & 10 & 10 & 10 & 10 \\
\hline Balance & 7.58 & 7.67 & 7.17 & 7 & 7.42 & 7.5 & 7.25 & 7,5 & 7.5 \\
\hline Clean Cup & 10 & 10 & 10 & 10 & 10 & 10 & 10 & 10 & 10 \\
\hline Overall & 7.58 & 7.75 & 7 & 7.42 & 7.5 & 7.5 & 7.17 & 7.5 & 7.5 \\
\hline Final Score & 81.08 & 81.83 & 77.33 & 78 & 80.25 & 80.50 & 78.33 & 79.67 & 79.9 \\
\hline
\end{tabular}

Note: A1B1 (0:1), A1B2 (0:3), A2B1 (1:1), A2B2 (1:3), A3B1 (2:1), A3B2 (2:3), A4B1 (3:1), A4B2 (3:3);

Based on Robusta coffee flavor test data, the characteristics of fragrance and flavor in all treatments have a score range of 7.17-7.75 indicating that coffee is very good (7.00-7.75). The treatment of A3B2 (2\% starter kefir, lactose $3 \%$ ) has the highest fragrance score of 7.75 , compared to the other treatments. Fragrance is an aspect of scent that includes the smell of coffee when it is dry or powder, while the smell is odor when the coffee is brewed with hot water. Treatment addition of starter kefir with lactose media influences the aroma of coffee produced because of the process of breaking lactose into glucose by lactic acid bacteria (LAB). Glucose is used as a source of energy to produce metabolism in the form of organic acids which later functions as a precursor to the formation of flavor in coffee [26]. In addition, the temperature of roasting also affects the formation of fragrance value or aroma of coffee beans. The standard roasting (medium) of aromatic components forms chocolaty aroma, but higher warming (dark) will burn the compounds aside sugar browning [4].

Flavor is a special trait between aroma, acidity, and ends with an aftertaste. The value of coffee flavor includes the influence of the quality and complexity of the combined flavor and aroma when coffee is drunk. Robusta coffee with A1B2 treatment (0\% starter kefir, lactose 3\%) has the highest flavor score compared to that with other treatment that is equal to
7.75. This is due to the spontaneous LAB of the environment that participates in the formation of coffee flavor. These spontaneous bacteria work in the fermentation process and produce lactic acid, acetic acid, butyric acid, and propionic acid which contribute to the production of flavor [27].

The aftertaste characteristic is the long-lasting positive flavor (flavor and aroma) that comes from the ceiling of the back of the mouth and persists after the coffee is swallowed (discarded). Based on data Table 4.1, all the treatments of Robusta coffee have a score above 7 , which means very good category (7.00-7.75). Treatment A4B1 (3\% kefir starter, lactose $1 \%$ ) has the highest score of 7.92. According to UCDA (2010), the value of low aftertaste means that coffee has a short aftertaste which can be caused by too strong or dominating acidity [21].

Good acidity describes coffee that is delicious, sweet, and fresh like fresh-fruit which is directly felt when coffee is sipped. Treatments of A1B2 (0\% starter kefir, lactose 3\%) and A3B2 (2\% starter kefir, lactose 3\%) have the highest acidity score of 7.83. This can be due to lactose as much as $3 \%$ optimizing the work of LAB where lactose is used as growth substrate. Lactic acid bacteria convert simple sugars into lactic acid, so the acidity value increases [28]-[29].

Sweetness characteristic is interpreted with a sweet taste in coffee. Treatment A1B2 (0\% starter kefir, lactose 3\%) has the highest sweetness score of 7.92. The emergence of sweetness characteristics in coffee beans is caused by the time of fermentation process decomposition of carbohydrates into glucose that affects the sweet taste [30]. With the high sweetness value of the A1B2 sample, the bitterness character will decrease, as more and more proteins break down into amino acids. As Marcone (2004) points out, the lower the protein content, the more coffee is not bitter, one of the proteins that decompose is caffeine [31].

Mouthfeel/body is based on the taste when the fluid enters the mouth especially between the tongue and the palate. Table 3.1 shows that control or coffee that is not given any treatment has the highest mouthfeel/body score of 7.92. Basically, coffee contains several carbohydrates namely arabinose, fructose, mannose, galactose, and glucose that are not degraded by kefir $\mathrm{LAB}$ without the treatment of fermentation. According to Yusianto et. Al. (2013), the carbohydrates trigger the occurrence of brown color in roasted coffee beans and very instrumental in the formation of volatile compounds and strengthen mouthfeel/body [4].

Uniform cup is the uniformity of the aroma of each bowl, while the clean cup shows no negative value from the beginning of the flavor until aftertaste as the end. The result of uniform and clean cup testing for all samples were 10, so it can be stated that all treatments have uniformity, and nothing can affect the flavor.

All aspects including flavor, aftertaste, acidity, sweetness, and mouthfeel. The highest LAB score was from sample A1B2 
(starter kefir 0\%, lactose 3\%) of 7.67. This corresponds to the aspect values of flavor, acidity, sweetness, and mouthfeel which all have the highest scores as described previously. Last is the overall aspect of a sample perceived by each panelist. Treatment A1B2 (0\% starter kefir, lactose 3\%) has the highest overall score of 7.75. This is in accordance with the final score stating that the treatment A1B2 has the highest final score of 81.83 and is included in the category of special or excellent (8.00-8.75).

Taint is a scent defect in coffee which is generally given a score of 2 if it detects the defect, while the faults are flaw defects which are generally rated 4 if found defective [32]. Based on the test, the taint and fault attribute on all four samples has a value of 0 . This indicates that all samples have no flavor defects. If the coffee sample has a score on taint and fault, it will lower the final score of coffee because these two attributes are not expected to appear.

There are 4 coffee samples that receive special coffee predicate; A1B2 treatment with score of 81.83 , treatment A1B1 with score of 81.08 , treatment A3B2 with score of 80.50, and treatment A3B1 with score of 80.25. Based on the results of the assessment, the concentration of $0 \%$ starter kefir and 3\% lactose gains the highest final score. This can be due to the occurrence of fermentation by spontaneous microbes that participate in the fermentation process to break down lactose. Meanwhile, the lowest final score of treatment A2B1 (starter kefir $1 \%$, lactose $1 \%$ ) of 77.33 was included in the category of very good (7.00-7.75).

\section{Volatile Compound Robusta Coffee}

Robusta coffee volatile compounds were carried out on each class of previously identified flavor components using GCMS. Tests were performed on A1B2 samples $(0 \%$ starter kefir, lactose 3\%), A2B1 (1\% starter kefir, lactose 1\%), and control. The selection of this sample was based on coffee that has the highest and lowest taste test scores as well as nontreated coffee samples or controls. Flavor profile analysis was done with the aim of identifying the influence of a component or compound to the aroma of coffee produced. The specific flavor component compounds are classified into 9 groups of flavor components, including phenols, furans, hydrocarbons, pyridine, pyrazine, benzene, organic acids, alcohols and aldehydes. Flavor test data were presented in Table 3.2.

Based on the data in Table 3.2, the number of flavor components between samples were different; the control sample has the total number of flavor components of 73 components while A1B2 sample (0\% starter kefir, lactose 3\% has the largest number of flavor components, 82 components and A2B1 $1 \%$ starter kefir, $1 \%$ lactose) has the lowest number of flavor components of 66. In this research, processing with microbial fermentation and roasting process will affect some groups of flavor components that are formed. Volatile compounds are derived from enzymatic products, fatty antioxidants, microbial activity results, thermal reaction products and environmental conditions. The combination of several volatile compounds will give a unique and distinctive flavor [33].

Table 3.2 Volatile Compounds of Robusta Coffee

\begin{tabular}{|c|c|c|c|c|}
\hline $\begin{array}{l}\text { Sample } \\
\text { Code }\end{array}$ & $\begin{array}{c}\text { Flavor } \\
\text { Components }\end{array}$ & $\begin{array}{c}\text { Total } \\
\text { Specific } \\
\text { Flavor } \\
\text { Compon } \\
\text { ents }\end{array}$ & $\begin{array}{c}\text { Total } \\
\text { Flavor } \\
\text { Compone } \\
\text { nts }\end{array}$ & Area \\
\hline \multirow{9}{*}{ Control } & Phenol & 3 & \multirow{9}{*}{73} & $4.93 \times 10^{8}$ \\
\hline & Furan & 2 & & $3.12 \times 10^{8}$ \\
\hline & Hidrocarbon & 46 & & $1.08 \times 10^{9}$ \\
\hline & Pyridine & 1 & & $1.03 \times 10^{7}$ \\
\hline & Pyrizine & 10 & & $6.35 \times 10^{8}$ \\
\hline & Benzen & 0 & & 0 \\
\hline & Organic acid & 7 & & $3.66 \times 10^{8}$ \\
\hline & Alcohol & 3 & & $4.22 \times 10^{8}$ \\
\hline & Aldehyde & 1 & & $6.92 \times 10^{6}$ \\
\hline \multirow{9}{*}{ A1B2 } & Phenol & 3 & \multirow{9}{*}{82} & $3.71 \times 10^{8}$ \\
\hline & Furan & 2 & & $4.15 \times 10^{8}$ \\
\hline & Hidrocarbon & 48 & & $1.02 \times 10^{9}$ \\
\hline & Pyridine & 1 & & $9.44 \times 10^{7}$ \\
\hline & Pyrizine & 12 & & $6.44 \times 10^{8}$ \\
\hline & Benzen & 1 & & $1.40 \times 10^{7}$ \\
\hline & Organic acid & 12 & & $5.17 \times 10^{8}$ \\
\hline & Alcohol & 2 & & $4 \times 10^{8}$ \\
\hline & Aldehyde & 1 & & $5.75 \times 10^{6}$ \\
\hline \multirow{9}{*}{$\mathrm{A} 2 \mathrm{~B} 1$} & Phenol & 3 & \multirow{9}{*}{66} & $2.09 \times 10^{8}$ \\
\hline & Furan & 4 & & $2.68 \times 10^{8}$ \\
\hline & Hidrocarbon & 38 & & $5.19 \times 10^{8}$ \\
\hline & Pyridine & 2 & & $1.15 \times 10^{7}$ \\
\hline & Pyrizine & 11 & & $4.06 \times 10^{8}$ \\
\hline & Benzen & 1 & & $5.16 \times 10^{6}$ \\
\hline & Organic acid & 5 & & $2.32 \times 10^{8}$ \\
\hline & Alcohol & 1 & & $2.68 \times 10^{8}$ \\
\hline & Aldehyde & 1 & & $7.97 \times 10^{6}$ \\
\hline
\end{tabular}

The three samples of Robusta coffee have a high percentage of hydrocarbon components compared to other flavor compounds. The identified hydrocarbon compound is a pyrrole 
compound. These compounds are formed from the degradation of amino acids when the process of roasting [32]. This pyrrole class compound contributes to the aroma of nutty, sweet and burnt [34].

The volatile compound having the next high percentage was pyrazine. Pyrazine is an aroma component formed by roasting in coffee. According to Caporaso et al. (2018), the pyrazine group compounds commonly identified in Robusta coffee beans are 2-methyl-pyrazine compounds; 2.6dimethylpyrazine; 2.5-dimethylpyrazine; ethylpyrazine, 2ethyl-6-methylpyrazine, 2-ethyl-5-methylpyrazine and 3ethyl-2.5-dimethyl pyrazine [35]. According to Lee et al. (2015), pyrazine compounds are formed from amino acid precursor compounds that occur when caramelized during roasting [36]. The compounds are reported to contribute to the smell of nutty, roasted, cocoa, chocolate and coffee in coffee [37]. Some of these compounds are allegedly more contributive to give the scent of chocolate and in accordance with the results of testing coffee beans test of asalan Robusta coffee with whole treatment that has a chocolate aroma.

The next volatile compound which has a high area was an organic acid. According to Caporaso et al. (2018), Robusta coffee generally has a high concentration of acetic acid [35]. Acid compounds in coffee contribute to acidy aroma. In this study, A1B2 coffee sample has a high organic acid area; this is caused by acid formation by the activity of lactic acid bacteria. Bressani et al. (2018), mention that lactic acid bacteria produce acid because of its metabolite. Based on the results of the test, it also can be seen that the characteristics of acidic aroma are identified in Robusta coffee seeds of A1B2 sample [28].

Another class of volatile compounds has a high percentage of the area of alcohol. The compounds included in the alcohol class in this study are 2-furanmethanol. This is in accordance with the literature which states that Robusta coffee, in general, has a high concentration of 2-furanmethanol volatile compounds [35]. This compound contributes to coffee burnt, sweet, caramel, coffee and bitter [34].

The compounds belonging to the phenol group in this study are 4-ethyl-2-methoxy phenol compounds; 2-methoxy4vinylphenol; and 2-methoxy phenol. Based on the research conducted by Lee et al. (2015), guaiacol compounds (2methoxy phenol) and pvinylguaiacol (2-methoxy-vinylphenol) have been enhanced by fermentation by yeast because the $\mathrm{p}$ vinylguaiacol compounds are formed when enzymatic decarboxylation of ferulic acid occurs while guaiacol is formed by redox reactions, decarboxylation oxidative and nonoxidative compounds of $p$ vinylguaiacol [36]. In the phenol class there are 2-methoxy-4vinylphenol compounds that contribute to the spicy aroma [38].

The next volatile compound that contributes to the taste of Robusta coffee is furan. This furan compound is formed due to thermal degration of carbohydrates, ascorbic acid, or unsaturated fatty acids during coffee roasting [39]. According to Mulato (2002), furan volatile compounds can cause caramel, oxazole, and sweet-hazelnut scent [40].

The pyridine component is formed from the chemical compounds of trigonelin during roasting progress. The process of overhauling in the final stage of $70 \%$ trigonelin will decompose into pyridine which has a big share in the formation of sweet and caramel flavor in the steeping of coffee [41]. The aldehyde group compound is one of the most important compounds in coffee because it contributes to the aroma of coffee. The volatile compounds of aldehyde group are furfural and benceneacetaldehyde compounds. These compounds contribute to the smell of sweet, burnt, caramel, nutty, fruity, and fatty [41]-[42]. According to Dan et al. (2017), aldehydes are the main volatile compounds present in fermented milk products that can increase volatiles [43]. It is assumed to cause the emergence of new compounds in the fermentation of asalan robusta coffee by using starter kefir. In addition to furfural and benceneacetaldehyde compounds, several caffeine compounds were detected; however, according to Burdock (2010), caffeine is a volatile compound that does not contribute to the aroma of coffee compounds [42].

\section{CONCLUSION}

Based on the results, fermentation using kefir starter was enhance cup test value by expert panels until 81.83 (specialty coffee) using $0 \%$ starter kefir and 3\% lactose. While, volatile compounds also increase, until 82 compounds (with added lactose $3 \%$ ).

\section{ACKNOWLEDGMENT}

I am deeply indebted to my supervisor, Professor Hiroyuki Harada for warm support, inspiration and thoughtful guidance. Also, I would like to thank to Takahashi Industrial and Economic Research Foundation and Professor Shinjiro Ogita for financial funding this research

\section{REFERENCES}

[1] Directorate General of Plantation, "Indonesian Plantation Statistics". Jakarta: Secretariat of Directorate General of Plantation Ministry of Agriculture, 2017.

[2] Misnawi and Sulistyowati, "Indonesian coffee quality and opportunities to increase its competitiveness". News Center for Indonesian Coffee and Cocoa Research, vol 22, pp. 127- 132, 2006.

[3] Ismayadi, C., "The taste of Indonesia's special arabica coffee". News Center for Coffee Research and Indonesian Cocoa, vol 14, pp. 165-172, 1998.

[4] Yusianto, and S. Widyotomo. "Quality and taste of Arabica coffee Results of some fermentation treatments: temperature, type of container, and addition of 
fermentation agent". Pelita Perkebunan vol 29 (3): pp. 220239, 2013.

[5] Mayrowani, H. "Policy on supply of post-harvest coffee technology and its development issues". Agro Economic Research Forum, vol 31 (1): pp. 31-49, 2013.

[6] Tramsek, M. and Gorsek, A. "Analysis of growth models for batch kefir grain biomass production in $\mathrm{RC} 1$ reaction system”. J. Food Process. Eng, vol 31, pp. 754-767, 2008.

[7] Tratnik, L., Bozanic, R., Hergec, Z., Drgalic, I. "The quality of plain and supplemented kefir from goat's and cow's milk”. Int. J. Dairy Technol, vol 59, pp. 40-46, 2006.

[8] Wroblewska, B., Kolakowski, P., Pawlikowska, K., Troszynska, A., Kaliszewska, A. "Influence of the addition of transglutaminase on the immunoreactivity of milk proteins and sensory quality of kefir". Food Hydrocoll, vol 23, pp. 2434-2445, 2009.

[9] Leite, A. M.O., D. C. A. Leite, M. D. Aguila, T. S. Alvares, R. S. Peixoto, M. A. L. Miguel, J. T. Silva, and V. M. F. Paschoalin. "Microbiological and Chemical Characteristics of Brazilian Kefir During Fermentation and Storage Processes”. J. Dairy Sci, vol 96: pp. 1-11, 2013

[10] Garrote, G.L, et al. "Preservation of kefir grains a comparative study". LebensmWiss. U.-Technol, vol 30, pp. 77-84, 1997.

[11] Dimitrellou, et al. "Whey-cheese production using freezedried kefir culture as a starter". J. Appl. Microbiol, vol 103, pp. 1170-1183, 2007.

[12] Papavasiliou, G., Kourkoutas, Y., Rapti, A., Sipsas, V., Soupioni, M. and Koutinas, A.A. "Production of freezedried kefir culture using whey". Int. Dairy J, vol 18, pp. 247-254, 2008.

[13] Ferreira, et al. "Effect of kefir grains on proteolysis of major milk protein". J. Dairy Sci, vol 93, pp. 27-31, 2010.

[14] Oktaviana, A. Y., D. Suherman, and E. Sulistyowati. "Effect of yeast tape on $\mathrm{pH}$, lactic acid bacteria and lactose yoghurt". Jurnal Sain Peternakan Indonesia 10 (1), 2015.

[15] Saragih, J. R. "Arabica Specialties Coffee Production of North Sumatra: Socio-Economic Analysis, Ecology and Policy of Local Government", 2016, https://www.google.com/ [Retrieved on March 28 Schwan, R. F. and G. H. Fleet. 2015. Cocoa and Coffee Fermentation. New York: CRC. Press.
[16] Specialty Coffee Association of America. "SCAA Protocols: Cupping Specialty Coffee". America: the Specialty Coffee Association of America, 2015.

[17] Hernani, and W. Haliza. "Optimization of nutrient composition for the formation of flavor components in fermentation of cocoa beans". Postharvest Journal, vol 10 (2): pp. 74-82, 2013.

[18] Riansyah, R. "Decreased Levels of Caffeine Coffee of Arabica Varieties with Koji Concentration and Old Fermentation". Thesis. Department of Food Technology. Faculty of Engineering. University of Pasundan, 2016.

[19] Fardiaz. S. "Food Microbiology". Inter-University Center for Food and Nutrition. Bogor Agricultural Institute, 1989.

[20] Muchtadi, T. R., Sugino and F. Ayustaningwarno. "Food Science Science". Bandung: Alfabeta, 2010.

[21] Uganda Coffee Development Authority. "Robusta Cupping Protocols. London: International Coffee Organization”, 2010.

[22] MacCabe, AP. "Industrial Enzymes; Structure, Function, and Applications". Dordrecht: Springer. Page: 24. ISBN 978-1-4020-5376-4, 2007.

[23] Budiman, H. Rahmawati, F. Sanjaya, F. "Isolation and Alkaloid Identification on Robusta Coffee (Coffea robusta Lindl. Ex De Will) By Way Thin layer chromatography". CERATA Journal of Pharmacy Sience, vol 1 (1): pp. 5464, 2010

[24] Wilujeng, A. A. T. and P. R. Wikandari. "The Influence of Old Coffee Fermentation Arabica (Coffea arabica) with Lactic Acid Lactobacillus Bacteria plantarum B1765 Against Product Quality”. Journal of Chemistry, vol 2 (3): pp. 1-10, 2013.

[25] Wardani, S. K., M. N. Cahyanto, E. S. Rahayu and T. Utami. "The Effect of Inoculum Size and Incubation Temperature on Cell Growth, Acid Production and Curd Formation during Milk Fermentation by Lactobacillus plantarum Dad 13”. International Food Research Journal, vol 24 (3): pp. 921-926, 2017.

[26] Avallone, S., J. M. Brillouet, B. Guyot, E. Olguin, and J.P. Guiraud. "Involvement of pectolytic microorganisms in coffee fermentation". International Journal of Food Science and Technology. vol 37: pp. 191-198, 2001.

[27] Jackels, S. C. and C. H. Jackles. "Characterization of the coffee mucilage fermentation process using chemical indicator: a field study in Nicaragua". Journal of a Food 
Science. vol 70 (5): pp. 321-325. Jakarta: Ministry of Health Republic of Indonesia, 2005.

[28] Bressani, A. P. P., et al. "Characteristics of Fermented Coffee Inoculated with Yeast Starter Cultures Using Different Inoculation Methods." Food Science and Technology, vol 92: pp. 212-219, 2018.

[29] Pereira, G. V. D. M., E. Neto, V. T. Soccol, A. B. P. Medeiros, A. L. Woiciechowski, C. R. Soccol. "Conducting Starter Culture-Controlled Fermentations of Coffee Beans During on Farma Wet Processing: Growth, Metabolic Analyzes and Sensorial Effects". Food Research International, vol 75: pp. 384-356, 2015.

[30] Redgwell, R. and fischer, M. "Coffee carbohydrates". Brazilian journal of plant physiology vol (1): 165-174, 2006.

[31] Marcone, N. F. "Composition and properties of Indonesian palm civet coffee and ethiopian civet coffee". Food Research International, vol 37 (9): pp. 901-912, 2004.

[32] Poltronieri, P. And F. Rossi. "Review Challenges in Specialty Coffee Processing and Quality Assurance". Challenges 7: 19, 2016.

[33] Alasalvar, C. Taylor, K. Syahidi, F. "Comparison of Volatile of Cultured and Wild Sea Bream (Sparus Auorota) during Storage in Ice by Dynamic Headspace Analysis / GCMS". J.Agric. Food Chem, vol 53: pp. 2612-2622, 2005.

[34] Zapata, J., V. Londono, M. Naranjo., J. Osorio, C. Lopez and M. Quintero. "Characterization of Aroma Compounds Present in An Industrial Recovery Concentrate of Coffee Flavor". Journal of Food vol 16 (1): pp. 367-372, 2018.

[35] Caporaso, N., M. B. Whitworth, C. Cui and I. D. Fisk. "Variability of Single Bean Coffee Volatile Compounds of Arabica and Robusta Roasted Coffees Analyzed by SPME-GC-MS". Food Research International, vol 108: pp. 628-640, 2018.

[36] Lee, L. W., M. W. Cheong, P. Curran, B. Yu, and S. Q. Liu. "Coffee Fermentation and Flavor - An Intricate and Delicate Relationship". Journal of Food Chemistry, vol 185: pp. 182-191, 2015.

[37] Kivancli, J. and Y. Elmaci. "Characterization of Turkishstyle Boiled Coffee Aroma by GC/MS and Descriptive Analysis Techniques". International Journal of Food Properties, 2015.

[38] Cannon, R. J., L. Trinnaman, B. Grainger and A. Trail. "The Key Odorants of Coffee from Various Geographical Locations". Washington DC: American Chemical Society, 2010.

[39] Sunarharum, W. B. 2016. "The Compositional Basis of Coffee Flavor. Thesis. Australia. The University of Queensland", 2016.
[40] Mulato, S., and Suharyanto, E. "Coffee, Seduhan, and Health. Jember: Research Center for Coffee and Cocoa", 2012.

[41] Burdock, G. A. "Fenaroli's Handbook of Flavor Ingredients Sixth Edition". London: CRC Press, 2010

[42] Dan, T., T. Wang, S. Wu, R. Jin, W. Ren, and T. Sun. "Profiles of Volatile Flavor Compounds in Milk Fermented with Different Proportional Combinations of Lactobacillus delbrueckii subsp. Bulgaricus and Streptococcus thermophilus. Molecules", vol 22: pp. 1633, 2017. 